\title{
Menyingkap Maqasid Profetik \\ Dalam Hadis Tentang Relasi Laki-Laki Dan Perempuan
}

(Revealing the Prophetic Maqasid in the Hadith About Relationships between Men and Women)

\author{
Umma Farida $^{1}$, Hardivizon ${ }^{2}$, Abdurrohman Kasdi ${ }^{3}$ \\ ${ }^{1,3}$ Institut Agama Islam Negeri (IAIN) Kudus, ${ }^{2}$ Institut Agama Islam Negeri (IAIN) Curup \\ 1'ummafarida@iainkudus.ac.id, ${ }^{2}$ hardivizon@iaincurup.ac.id, ${ }^{3}$ abdurrohmankasdi@iainkudus.ac.id
}

DOI: $10.29240 /$ alquds.v5i2.3319

Submitted: 2021-08-16 | Revised: 2021-11-02 |Accepted: 2021-11-28

\begin{abstract}
The textual reading of the Prophet's hadith about the relationship between men and women often results in discriminatory and subordinating attitudes towards certain genders. This article aims to reread the hadith about the relationship between men and women. It emphasizes the disclosure of prophetic Maqasid or the orientation and purpose of prophethood in the hadith. This study uses a descriptive-analytical method by criticizing the traditions about the relationship between men and women contained in the books of Sunan Abi Dawud, al-Tirmidzi, and al-Darimi. The result shows that revealing the prophetic Maqasid in these traditions is urgent considering that the purpose of Muhammad's sending was to spread love to the universe based on monotheism (Tawhid). Tawhid is not only a verbal statement. It becomes the main foundation in building a socio-political-cultural order that promotes equality and balance between men and women. A balanced and harmonious relationship between the two becomes the Maqasid of the Prophet in every utterance and policy he established. The balance of relations between men and women by relying on a correct and comprehensive understanding of the hadith of the Prophet opens opportunities for women to perform and play the roles that need them for the good of humanity universally.
\end{abstract}

Keyword: Hadith; Prophetic Maqasid; Male and female relations; Tawhid

Abstrak. Pembacaan tekstual terhadap hadis Nabi saw. tentang relasi laki-laki dan perempuan tidak jarang berakibat pada sikap diskriminatif dan subordinatif terhadap jenis kelamin tertentu. Artikel ini bertujuan untuk melakukan pembacaan ulang terhadap hadis tentang relasi laki-laki dan perempuan dengan menekankan pada penyingkapan Maqasid profetik atau orientasi dan tujuan kenabian dalam hadis tersebut. Penelitian ini disusun dengan menggunakan metode deskriptif analitis dengan mengkritisi hadis-hadis tentang relasi laki-laki dan perempuan yang termaktub dalam kitab Sunan Abi Dawud, alTirmidzi, dan al-Darimi. Hasil penelitian menunjukkan bahwa menguak Maqasid profetik dalam hadis-hadis tersebut menjadi penting mengingat tujuan pengutusan Muhammad 
adalah untuk menebar kasih pada semesta dengan landasan Tauhid. Tauhid bukan hanya merupakan pernyataan verbal, melainkan sebagai landasan utama dalam membangun tatanan sosial-politik-kebudayaan yang mendorong kesetaraan dan keseimbangan relasi antara laki-laki dan perempuan. Relasi yang berimbang dan harmonis antara keduanya menjadi Maqasid Nabi saw. dalam setiap ujaran dan kebijakan yang ditetapkannya. Keseimbangan relasi antara laki-laki dan perempuan dengan bersandar pada pemahaman yang tepat dan komprehensif terhadap hadis Nabi saw. membuka kesempatan dan peluang bagi kaum perempuan untuk berprestasi dan memainkan peran-peran yang membutuhkan mereka demi kemaslahatan kemanusiaan secara universal.

Kata Kunci : Hadis; Maqasid profetik; Relasi laki-laki dan perempuan; Tauhid.

\section{Pendahuluan}

Membincang relasi laki-laki dan perempuan dalam konteks kritik wacana keagamaan selalu menarik diperbincangkan, terlebih jika hal itu menyangkut tentang perilaku Nabi saw. dan kehidupan keseharian masyarakat muslim generasi awal Islam. ${ }^{1}$ Bahkan, kontroversi dalam mengkajinya juga terkadang sulit terelakkan, karena tidak jarang melibatkan sistem emosional yang berpengaruh dalam kehidupan manusia. Yaitu, emosi keimanan yang sangat kuat di satu sisi untuk menjaga tradisi agama yang telah terwarisi dari generasi ke generasi, dan di sisi lain, adanya semangat melakukan pembacaan ulang atas teks-teks keagamaan yang terkesan misogynis dan diskriminatif. ${ }^{2}$

Sabda, ujaran, dan perbuatan Nabi saw. yang terangkum dalam hadis senantiasa menginspirasi dan mempengaruhi tradisi kehidupan umat Islam seharihari. ${ }^{3}$ Mereka meyakini bahwa Nabi memiliki otoritas yang tidak hanya berasal dari penerimaan umat terhadapnya, melainkan diperteguh oleh kehendak Allah dan firman-Nya dalam al-Qur'an. Di antara otoritas yang dimiliki Nabi saw. yakni menjadi teladan berperilaku (role model) yang ditaati bagi masyarakat muslim (QS. Al-Ahzab: 21; al-Nisa': 59 \& 64; Ali 'Imran: 32 \& 132), ${ }^{4}$ memperjelas isi dan petunjuk al-Qur'an (QS. Al-Nahl: 44), dan menetapkan suatu legislasi hukum (QS. Al-A'raf: 157) serta memprakarsai hal-hal tertentu sebagai praktik masyarakat muslim yang baku, seperti azan, ataupun mengeluarkan larangan tertentu, seperti memadu bibi dan keponakan perempuannya dalam pernikahan. Al-Azami

${ }^{1}$ Khalil Abd al-Karim, Mujtama Yatsrib Alaqah Al-Rajul Wa Al-Mar'ah Fi Abd Al-Nabiy Wa Al-Kbulafa Al-Rasyidin (Cairo: Sina li al-Nasyr, 1997), 35-42.

${ }^{2}$ Kadarusman, Agama, Relasi Gender \& Feminisme (Yogyakarta: Kreasi Wacana, 2005), 1.

${ }^{3}$ Muhammad Mustafa al-Azami, Studies in Hadith Methodology and Literature (Indianapolis: American Trust Publications, 1977), 3-6.

${ }^{4}$ Umma Farida, Abdurrohman Kasdi, 'Women's Roles in Ihya 'Ulum Al-Din and Method of Teaching It at Pesantrens in Indonesia', Al-Jami' ah Journal of Islamic Studies, 59.1 (2021), 163-90 (164). https://doi.org/10.14421/ajis.2021.591. 
menegaskan bahwa ketetapan, perintah, dan larangan Nabi saw. memiliki otoritas yang mengikat dalam kehidupan umat Islam. ${ }^{5}$

Oleh karena itu, tidak sedikit umat Islam yang menerima apapun ujaran Nabi saw. dan memahaminya secara tekstual dengan mengesampingkan tujuan, konteks, serta latar belakang historis dan sosiologis dikeluarkannya sabda tersebut, seperti dalam memahami hadis-hadis tentang relasi laki-laki dan perempuan. Mayoritas masyarakat masih berpandangan bahwa kaum perempuan adalah makhluk Tuhan kelas dua di hadapan laki-laki. Laki-laki selalu dipersepsikan memiliki wilayah peran publik, sedangkan peran perempuan terbatas hanya dalam wilayah domestik. ${ }^{6}$ Persepsi yang berasal dari budaya patriarkhi ini selanjutnya melahirkan perbedaan wilayah aktualisasi diri antara keduanya.

Ketimpangan relasi ini menjadi semakin nyata karena merebaknya pemahaman tekstualis terhadap hadis yang turut melanggengkan konstruksi budaya patriarkhis tersebut, padahal dengan pendekatan Maqasid al-Shariah maka pemahaman terhadap hadis dapat dikontekstualisasikan dengan menggali tujuantujuan Nabi saw. selaku sumber hadis dalam menyabdakan hadis tersebut, sehingga dapat meminimalisir bahkan menghindarkan kesan misogynisdiskriminatif dalam memahami hadis.

Penelitian ini disusun dengan menggunakan metode penelitian deskriptif-analitis. Metode ini bertujuan untuk memperoleh pemaparan objektif atas sebuah masalah melalui proses analisis. ${ }^{7}$ Dalam hal ini, penulis memfokuskan perhatian pada permasalahan yang menjadi pertanyaan penelitian, yaitu pemahaman terhadap tujuan dan orientasi kenabian (Maqasid profetik) dalam hadis tentang relasi laki-laki dan perempuan. Dalam hal ini, penulis melakukan studi pustaka terhadap literatur yang berhubungan dengan kajian Maqasid alShariah dan hadis-hadis tentang relasi laki-laki dan perempuan yang termaktub dalam kitab Sunan Abi Dawud, al-Tirmidzi, dan al-Darimi. Hasil penelitian kemudian diolah dan dianalisis untuk pengambilan kesimpulan.

${ }^{5}$ Al-Azami, Dirasat Fi Al-Hadis an-Nabawi Wa Tarikh Tadwinih (Beirut: Al-Maktab alIslami, 1992), 12.

${ }^{6}$ Mulyadi, 'Relasi Laki-Laki Dan Perempuan: Menabrak Tafsir Teks, Menakar Realitas', Al-Ibkam, IV.1 (2009), 52-55.

${ }^{7}$ Abdul Syukur Ibrahim, Metode Analisis Teks Dan Wacana (Yogyakarta: Pustaka Pelajar, 2009), 107. 


\section{Maqasid Profetik: Ikhtiar Mengungkap Maqasid al-Shari'ah dalam Ujaran Nabi}

\section{Pengertian Maqasid Profetik}

Mengkaji teks-teks keislaman dengan menggunakan pendekatan Maqasid al-Shariah akhir-akhir ini semakin banyak diminati di belahan dunia Islam, termasuk Indonesia. Meskipun kajian Maqasid al-Shari'ah sebenarnya bukanlah hal baru, namun kembali mengemuka setelah Ibn Ashour melakukan pembaruan kajian Maqasid ini dan mengkaitkannya dengan tafsir al-Qur'an dalam karyanya, Maqasid al-Shari'ah al-Islamiyyah dan al-Tahrir wa al-Tanwir. ${ }^{8}$ Dari sini kemudian berkembang kajian-kajian al-Qur'an dengan pendekatan Maqasid atau yang lazim disebut dengan Maqasid al-Qur'an dan Tafsir Maqasidi.

Respon masyarakat Indonesia dalam menggalakkan Tafsir Maqasidi tidak diimbangi dengan maraknya kajian-kajian hadis dengan pendekatan Maqasid pula. Meskipun secara epistemologis pendekatan Maqasid ini berasal dari keilmuan Islam, bukan dari keilmuan Barat seperti halnya pendekatan Hermeneutik. Selain itu, pendekatan Maqasid juga bisa menjadi alternasi dalam menyeimbangkan pemahaman terhadap teks-teks hadis sehingga tidak terjebak dalam pemahaman tekstual-fundamental ataupun pemikiran liberal yang mendesakralisasi kemuliaan teks hadis.

Dalam tiga tahun terakhir ini, beberapa cendekiawan Muslim tampak berupaya mengkaitkan Maqasid al-Shari'ah dan menerapkannya dalam kajian hadis, seperti Abdullah Mohammad Charbgoo, Fatima Hafiz Irshudul Haq, dan Kassem Ali Saad dari University of Sharjah Uni Emirat Arab dalam paper mereka, The Effect of the Purposes of Shari'a on the Understanding of Hadiths. ${ }^{9}$ Juga, Abdelhamid Majid Ismail dari Istanbul University dalam papernya, The Relationship of the Science of the Makassed of Sharia to Hadeeth Science. ${ }^{10}$ Sebelumnya, Hasan Abdullah Hasan Ma'touq dari al-Najah University Palestina, yang menulis paper yang berjudul alBu'd al-Maqasidi li al-Hadis al-Sharif wa Tathbiqatibi 'ind al-Fuqaba, ${ }^{11}$ kemudian Muhammad Rozaimi bin Ramle dari Universiti Pendidikan Sultan Idris Malaysia yang menulis paper yang berjudul Fahm al-Hadits fi Dhau'i al-Maqasid al-Shar'iyyah:

2004).

${ }^{8}$ M. al-Tahir Ibn Ashour, Maqasid Al-Shariah Al-Islamiyyah (Amman: Dar al-Nafais,

${ }^{9}$ Abdullah Mohammad Charbgoo, Fatima Hafiz Irshudul Haq, Kassem Ali Saad, 'The Effect of the Purposes of Shari'a on the Understanding of Hadiths', Majallah Al-Shariqah Li AlUlum Al-Shar'iyyah Wa Al-Dirasat Al-Islamiyyah, 16.1 (2019), 27-61.

${ }^{10}$ Abdelhamid Majid Ismail, 'The Relationship of the Science of the Makassed of Sharia to Hadeeth Science', Majallah Al-Ijtibad Li Al-Dirasat Al-Qanuniyah Wa Al-Iqtisadiyah, 8.2 (2019), 69-89.

${ }^{11}$ Hasan Abdullah Hasan Ma'touq, Al-Bu'd Al-Maqasidi Li Al-Hadis Al-Sharif Wa Tathbiqatibi ind Al-Fuqaha (Palestina: al-Najah al-Wataniyyah University, 2018). 
Ta'shil wa Fawa'id wa Dhawabith, ${ }^{12}$ dan Abdullah Ibrahim Zayd al-Kaylani dari University of Jordan yang menulis paper Atsar al-Maqasid al-Juz'iyyah wa al-Kulliyyah fi Fahm al-Nushush al-Shar'iyyah: Dirasah Tathbiqiyyah min al-Sunnah al-Nabawiyyah yang menekankan pentingnya menggali Maqasid dalam memahami teks-teks hukum Islam dengan mengambil contoh teks hadis tentang larangan memakai pakaian panjang bagi kaum lelaki dan membaca puisi atau sya'ir. ${ }^{13}$

Sebelum mengulas lebih lanjut pengertian Maqasid Profetik dalam artikel ini, maka perlu diuraikan terlebih dahulu makna Maqasid al-Shari'ah yang menjadi basis keilmuan dalam memahami misi dan pesan kenabian dalam hadis. Maqasid merupakan jamak dari maqsad yang berarti tujuan, penentuan, dan orientasi terhadap sesuatu. ${ }^{14}$ Adapun akar kata dari maqshd ini adalah qasada yang berarti mendatangi dan berorientasi terhadap sesuatu (ityan al-shai'), adil, seimbang tidak berlebihan dan tidak serba kekurangan, ${ }^{15}$ konsisten dan jalan yang lurus (istiqamah al-thariq). ${ }^{16}$ Sedangkan definisi Maqasid al-Shari'ah telah banyak diungkap oleh para ulama. Ibn Ashour misalnya, mendefinisikan Maqasid al-Shariah sebagai makna dan hikmah yang diperhatikan oleh Syari' dalam keseluruhan atau sebagian besar bentuk dan ketentuan Syariat. ${ }^{17}$ Senada dengan Ibn Ashour, al-Raisuni mendefinisikan Maqasid al-Shariah sebagai tujuan yang ditetapkan Syariat untuk mewujudkan kebaikan (Maslabat) umat manusia. ${ }^{18}$ Demikian pula dengan Nur alDin al-Khadimi, menurutnya Maqasid al-Shariah adalah tujuan dan makna yang diperhatikan dalam hukum-hukum Syariat, baik yang berupa hikmah parsial ataupun kebaikan umum dan universal, yang keseluruhannya bermuara pada satu tujuan yaitu kemaslahatan manusia di dunia dan akhirat. Berdasar ragam definisi di atas, maka dapat dinyatakan bahwa Maqasid profetik adalah tujuan dan hikmah yang diperhatikan oleh Nabi saw. sebagai sumber hadis dalam menyampaikan sabda dan misi pengutusan dirinya (Risalah) untuk merealisasikan kebaikan umat manusia. ${ }^{19}$

12 Muhammad Rozaimi Ramle, 'Fahm Al-Hadits Fi Dhau'i Al-Maqasid Al-Shar'iyyah: Ta'shil Wa Fawa'id Wa Dhawabith', Journal of Hadith Studies, 2015, 7-28.

${ }^{13}$ Abdullah Ibrahim Zayd al-Kaylani, Atsar Al-Maqasid Al-Juz'iyyah Wa Al-Kulliyyah Fi Fahm Al-Nushush Al-Shar'iyyah: Dirasah Tathbiqiyyah Min Al-Sunnah Al-Nabawiyyah (Yordania: University of Jordan, 2006), 15-29.

${ }^{14}$ Yusuf al-Qaradawi, Fi Fiqh Al-Awlawiyyat (Cairo: Maktabah Wahbah, 1999), 79.

${ }^{15}$ Muhamad bin Mukrim Ibn Mandzur al-Misri, Lisan Al-Arab, III (Beirut: Dar Shadir, 1990), 353.

${ }^{16}$ Ibn Mandzur al-Misri, 353.

${ }^{17}$ Ibn Ashour, 56.

18 Ahmad al-Raisuni, Nazhariyyah Al-Maqasid Ind Al-Imam Al-Shatibi (Rabat: Dar alAman, 1991), 7.

${ }^{19}$ Nur al-Din al-Khadimi, Al-Ijtihad Al-Maqasidi Hujjiyyatubu, Dhawabithubu, Majalatubu (Qatar: Wizarah al-Awqaf wa al-Syu’un al-Islamiyyah, 1998), 52-53. 
Al-Qur'an sebagai sumber hukum yang utama bagi umat Islam telah menegaskan bahwa misi pengutusan Muhammad adalah untuk menebar kasih bagi semesta (Rabmatan li al-'Alamin), (QS. al-Anbiya': 107). Selain itu, Al-Qur'an juga telah mendeskripsikan Nabi saw. sebagai orang yang memiliki perhatian dan kecintaan yang luar biasa demi kebaikan umat sebagaimana dinyatakan dalam QS. Ali Imran: 164 dan al-A'raf: 157. Nabi saw. selalu berpesan kepada para sahabatnya untuk memberikan kemudahan dan tidak mempersulit, menyampaikan kabar gembira dan bukan menyampaikan berita menakutkan yang membuat orang-orang menghindar. ${ }^{20}$ Bahkan, dari hadis pula muncul salah satu kaidah Fiqh yang berkaitan dengan Maqasid al-Shari'ah, yaitu Kaidah "Bahaya harus dihilangkan" (al-Dhararu Yuzal), ${ }^{21}$ yang berasal dari hadis, "Tidak ada sesuatu yang bahaya dan membahayakan" (La Dharara wa la Dhirara). ${ }^{22}$

Menguak hikmah dan tujuan (Maqasid) yang diperhatikan oleh Nabi saw. menjadi penting karena hadis merupakan salah satu sumber Syariat Islam disamping al-Qur'an. ${ }^{23}$ Adapun Syariat itu sendiri merupakan hukum yang menyiratkan kepada tujuan (Maqasid), sebagaimana Maqasid juga menyiratkan kepada hukum. ${ }^{24}$ Bahkan, Imam al-Shatibi menyatakan bahwa Maqasid merupakan ruh dari segala amalan hamba (al-Maqasid Arwah al-A'mal). ${ }^{25}$ Statemen al-Shatibi ini tidak terbatas pada tujuan dari amalan hamba yang Mukallaf saja, melainkan juga mencakup seluruh aspek. Al-Shatibi memformulasikan bahwa tujuan Syariat adalah untuk menjaga lima kebutuhan primer manusia, yakni penjagaan agama (Hifz̧ al-Din), penjagaan diri (Hifz̧b al-Nafs), penjagaan akal (Hifžb al-Aql), penjagaan keturunan (Hifžb al-Nasl), dan penjagaan harta (Hifžb alMal) yang keseluruhannya bersumber dari al-Qur'an dan Sunnah. Oleh karenanya, ruh al-Qur'an adalah tujuan (Maqasid)nya sebagaimana juga bahwa ruh Sunnah adalah tujuan Sunnah itu sendiri. Hukum Islam (Fiqh) tanpa Maqasid sama saja dengan Fiqh tanpa ruh. ${ }^{26}$

Urgensi menerapkan Maqasid dalam memahami sabda Nabi ini juga telah dilakukan oleh para sahabat Nabi saw. Hal ini ditunjukkan melalui sikap mereka

${ }^{20}$ Muhammad ibn Ismail ibn Ibrahim ibn al-Mughirah ibn Bardzibah Al-Bukhari, $A l$ Jami' Al-Sabih, I (Cairo: Dar al-Rayyan, 1997), 122.;Muslim bi al-Hajjaj Abu al-Hasan al-Qusyairi Al-Naisaburi, Al-Jami' Al-Sabih, II (Beirut: Dar al-Fikr, 2001), 154. 2000), 8 .

${ }^{21}$ Jalal al-Din al-Suyuti, Al-Ashbah Wa Al-Nazhair, I (Aleppo: Maktabah al-Bab al-Halabi,

${ }^{22}$ Ibn Majah, Sunan, III (Beirut: Dar al-Fikr, 1998), 143.

${ }^{23}$ Mustafa al-Siba'i, Al-Sunnah Wa Makanatuba Fi Al-Tasbri' Al-Islami (Beirut: Dar al-Fikr, 2001), 19.; al-Qaradawi, Kayfa Nata'amal Ma'a Al-Sunnah Al-Nabawiyab (Cairo: Dar al-Shorouk, 2000), 135.

${ }^{24}$ Ibn Ashour, 55-56.

${ }^{25}$ Ibrahim ibn Musa al-Shatibi, Al-Muwafaqat Fi Usul Al-Shariah, (Qatar: Qatar Foundation, 2012), 345.

${ }^{26}$ al-Raisuni, 19. 
tatkala Nabi saw. mengutus suatu pasukan rahasia yang dipimpin oleh seorang lelaki Anshar, dan Nabi saw. berpesan kepada pasukan itu untuk mendengar dan mematuhi pimpinannya. Suatu waktu, sang pemimpin memarahi anggota pasukannya hingga ia memerintahkan untuk mengumpulkan banyak kayu dan menyalakan api di atas kayu tersebut, lalu ia berkata: "Bukankah Nabi saw. memerintahkan kalian untuk mendengar dan mentaatiku?" Para anggota pasukan menjawab, "Ya." Si pemimpin kembali berkata, "Maka masuklah kalian ke dalam api yang membara itu." Mereka pun saling berpandangan, dan tidak mengikuti perintah si pemimpin tadi. Tatkala mereka pulang, mereka menyampaikan peristiwa itu kepada Nabi saw., maka beliau bersabda, "Seandainya kamu memasuki api itu, niscaya kalian terbakar dan tidak akan lagi bisa keluar darinya, sesungguhnya ketaatan itu hanyalah dalam kebaikan." ${ }^{27}$ Dalam menjelaskan hadis ini, Abu al-Abbas al-Qurthubi menyatakan jika para sahabat tidak memahami tujuan (Maqasid) Nabi saw. dalam menyampaikan sabdanya tersebut, dan hanya berpegang kepada tekstualitas sabda niscaya mereka justru akan menghadapi bahaya dan kehancuran. ${ }^{28}$

\section{Maqasid Profetik dalam Memahami Hadis}

Mengungkap Maqasid profetik dalam memahami hadis-hadis Nabi saw. hendaknya tidak dilakukan secara serampangan berdasar rasio murni semata. ${ }^{29}$ Agar tidak salah dalam menguak Maqasid profetik dari hadis-hadis Nabi saw., maka ada beberapa kaidah yang harus dipegangi antara lain: Pertama, kontekstualisasi makna hadis tidak boleh mereduksi makna tekstual teks. Ini artinya, penggunaan Maqasid dalam memahami hadis tidak boleh mengakibatkan pengabaian atau bahkan penafian terhadap makna denotatif-tekstual dari suatu lafal hadis kecuali ada argumen kuat yang mengharuskan penta'wilan atau beralih kepada makna konotatif. ${ }^{30}$ Kedua, Penerapan pemahaman Maqasidi tidak berlaku pada hadis-hadis yang berkaitan dengan hal-hal yang sifatnya Tauqifi, yakni penetapan dari Allah dan Nabi saw. melalui wahyu seperti urusan ibadah dan takdir, ${ }^{31}$ melainkan berlaku pada hadis-hadis Ijtihadi yang terbuka untuk berijtihad dalam memahaminya. Ketiga, mengutamakan pada tujuan (Maqasid) yang menjadi prioritas dan paling penting (Mura'at al-Ahamm fa al-Mubim), serta mengedepankan kemaslahatan universal yang berpijak pada prinsip-prinsip umum dalam Islam, seperti prinsip keadilan, kesetaraan, kesamaan dalam hukum, kasih sayang,

\footnotetext{
27 Al-Naisaburi, 372.

${ }^{28}$ Abu al-Abbas Ahmad ibn Umar al-Qurtubi, Al-Mufhim Lima Asykala Min Talkhish Kitab Muslim, IV (Damaskus: Dar Ibn Katsir, 1996), 40.

${ }^{29}$ Ismail, 88.

30 al-Kaylani, 103.; Ma'touq, 95-96.

${ }^{31}$ Ibn Daqiq al-Ied, Ibkam Al-Ahkam Syarh Umdat Al-Ahkam, I (Matba'ah al-Sunnah alMuhammadiyah, 1982), 203.
} 
menghindarkan kesulitan dan bahaya. ${ }^{32}$ Jika terjadi kontradiksi antara berbagai teks hadis maka sebaiknya mengutamakan pada hadis yang mengandung kebaikan (Maslabat) yang lebih kuat dan lebih dibutuhkan oleh umat manusia (Mura'at alAshlab fa al-Shalib), sebagaimana statemen Ibn Abd al-Salam bahwa keutamaan suatu amalan bergantung pada keutamaan kebaikan dan kemanfaatannya (Fadha'il al-A'mal Mabniyyah 'ala Fadha'il Mashalibiha). ${ }^{33}$ Keempat, penggunaan Maqasid untuk memahami hadis tidak mengakibatkan pertentangan dengan teks-teks Islam yang mengandung petunjuk pasti (Qath'iy), atau menyelisihi tujuan umum yang telah disepakati para ulama (Ijma).. ${ }^{34}$

Selain itu, ada pula beberapa hal yang penting untuk dicermati pula dalam menggali Maqasid dari hadis Nabi saw.: Pertama, pembedaan kapasitas beliau dalam bersabda atau berbuat, yakni membedakan kapasitas Nabi saw. antara sebagai Nabi, hakim yang menyelesaikan dan memutuskan suatu permasalahan atau konflik (qadhi), pemberi fatwa (mufti), dan kepala negara. ${ }^{35}$ Demikian pula dengan Ibn Ashour yang memperluas kapasitas Nabi saw. ini ke dalam 12 kondisi: sebagai sumber syariat, memberi fatwa, memutuskan suatu perkara, pemimpin negara, memberi petunjuk, juru damai, konsultan ketika ada seseorang yang datang berkonsultasi, memberi nasehat, menyempurnakan jiwa, mengajarkan hakekat moral yang luhur, mendidik, dan semata-mata memberikan bimbingan. ${ }^{36}$

Pentingnya pembedaan kapasitas Nabi saw. ini berdasar realitas bahwa meskipun mayoritas ulama bersepakat bahwa sunnah Nabi merupakan hukum syariat yang mengikat (tashri'izyah) berdasar QS. al-Hasyr: 7 dan al-Ahzab: 21, namun faktanya sebagian di antara hadis atau sunnah itu muncul sebagai respon atau solusi atas peristiwa-peristiwa tertentu dan pada tempat tertentu yang sifatnya kondisional, yang tidak tepat apabila diterapkan untuk kasus-kasus dalam kondisi dan tempat yang berbeda. Dengan demikian, dapat dinyatakan bahwa hukum asal dari kapasitas Nabi saw. adalah bahwa beliau merupakan sumber tasyri', sedangkan positioning kapasitas selain itu berlaku apabila ditemukan indikator (qarinab), dalil, atau argumen kuat yang mengarah pada kapasitas non-tasyri. Sebagai contoh, hadis tentang arah kiblat sebagaimana terkodifikasi dalam kitab Sunan al-Tirmid zi dari riwayat Abu Hurairah yang menyebutkan bahwa arah antara Timur dan Barat adalah kiblat. ${ }^{37}$ Teks hadis ini tepat bagi masyarakat Madinah yang secara geografis berada di utara Ka'bah (Makkah). Menurut Ali Mustafa Ya'qub, memahami hadis tentang arah kiblat ini bagi masyarakat Indonesia harus secara kontekstual, karena

\footnotetext{
32 al-Kaylani, 103.

${ }^{33}$ Izzuddin Ibn Abd al-Salam, Al-Qawa'id Al-Sughra (Beirut: Dar al-Fikr al-Mu'asir, 1996),

${ }^{34}$ Charbgoo, Haq, Saad, 35-36.

${ }^{35}$ Syihab al-Din al-Qarafi, Al-Furuq, I (Beirut: Dar al-Kutub al-Ilmiyah, 2009), 205.

${ }^{36}$ Ibn Ashour, 212.

${ }^{37}$ Abu Isa Muhammad ibn Isa Al-Tirmizi, Sunan, II (Beirut: Dar al-Fikr, 2000), 73-74.
} 144. 
secara geografis arah kiblat bagi masyarakat Indonesia terletak di antara arah utara dan selatan. ${ }^{38}$

Kontekstualisasi dalam memahami tujuan Nabi saw. dalam hadis beliau ini sudah berlaku sejak masa para sahabat Nabi. Umar ibn al-Khattab misalnya, ketika ia menjadi khalifah ia tidak membagi tanah Irak kepada prajurit perang pasca penaklukan wilayah Irak tersebut karena pertimbangan kebaikan umum atau kemaslahatan yang lebih luas, ${ }^{39}$ meskipun sebenarnya ia mengetahui adanya hadis tentang pembagian tanah Khaybar yang dilakukan oleh Nabi saw. kepada para prajurit perang setelah penaklukan tanah tersebut. Melihat sikap Umar ini, para ulama tidak berpandangan bahwa Umar melakukan penentangan terhadap sunnah Nabi saw. Dalam hal ini, Yusuf al-Qaradawi menjelaskan bahwa hadis tersebut muncul bukan dalam kapasitas beliau sebagai Nabi (non-tashri'iy). ${ }^{40}$ Dengan pertimbangan kemaslahatan, Umar tidak membagi-bagi tanah Irak tersebut kepada para prajurit, melainkan ia mewakafkannya sebagai investasi berkelanjutan untuk kemaslahatan para generasi umat Islam, produk hasil bumi yang dihasilkan tanah tersebut berguna untuk membiayai para prajurit perang dan para pegawai pemerintahan. ${ }^{41}$ Dengan demikian, tujuan (Maqasid) Nabi saw. membagi-bagi tanah taklukan memang relevan pada masanya, namun pada masa berikutnya, yakni pada masa Umar, ia melihat adanya tujuan yang lebih luas dimana kebutuhan masyarakat Muslim yang terus berkembang pun menjadi semakin banyak.

Kedua, menggali Maqasid dari suatu hadis bukanlah berarti bahwa kesahihan suatu hadis bergantung pada Maqasidnya. Tidaklah tepat dikatakan bahwa jika matannya sesuai dengan tujuan Syariat yang diperhatikan Nabi saw., maka hadis tersebut berstatus diterima (maqbul), sedangkan jika suatu teks hadis bertentangan dengan Maqasid al-Shari'ah maka hadis tersebut secara otomatis tertolak (mardud). ${ }^{42}$ Ini disebabkan jika hal ini dibenarkan maka terbuka peluang untuk secara gegabah menerima atau menolak suatu hadis, sementara dalam tradisi Muhaddisin berlaku ketentuan bahwa untuk memastikan kualitas kesahihan suatu hadis harus diteliti terlebih dahulu 5 (lima) aspek yang meliputi: kebersambungan sanad, keadilan periwayat dan kekuatan hafalan mereka, tidak ada kejanggalan dan cacat. Adapun hadis-hadis yang dapat digali Maqasid nya merupakan hadis-hadis yang dapat diterima (maqbul), yakni hadis sahih dan

38 Ali Mustafa Ya’qub, Haji Pengabdi Setan (Jakarta: Pustaka Firdaus, 2006), 155.

${ }^{39}$ Ismail, 76.

${ }^{40}$ Yusuf al-Qaradawi, Al-Sunnah Mashdaran Li Al-Ma'rifah Wa Al-Hadharah (Cairo: Dar al-Shorouk, 1998), 79.

${ }^{41}$ Tarmizi M Jakfar, Otoritas Sunnah Non-Tasyri'iyyah Menurut Yusuf Al-Qaradhawi (Yogyakarta: Arruzz Media, 2011), 19.

42 Ismail, 81-83. 
hasan. ${ }^{43}$ Demikian pula dengan matannya yang harus memenuhi kualifikasi kesahihan matan yang tidak boleh menyelisihi al-Qur'an, Sirah al-Nabawiyyah dan Sunnah Mutawatirah, rasio, bukti empirik dan juga kenyataan sejarah. ${ }^{44}$

Ketiga, memahami hadis secara komprehensif. Sering kali problem pemahaman terhadap suatu teks muncul berawal dari pemahaman teks secara parsial. Oleh karenanya, para muhaddisin sejak lama telah mentradisikan untuk mengkompilasi hadis-hadis setema terlebih dahulu sebelum menentukan kualitas hadis dan menjelaskan kandungan maksud dari hadis tersebut. Demikian pula dalam upaya menggali tujuan Nabi saw. yang terekam dalam ujaran beliau pun perlu dilakukan pengkajian hadis secara komprehensif, sebagaimana statemen Ibn al-Madini yang dikutip Ibn al-Salah al-Shahrazuri, "Memahami suatu perkara dalam hadis jika tidak dikumpulkan terlebih dahulu seluruh jalur hadisnya, maka tidak akan jelas letak kesalahannya." 45

Keempat, memperhatikan gaya bahasa Arab dan konteks kalimatnya, serta latar belakang historis (Asbab al-wurud) dari ujaran dan perbuatan Nabi saw. Selain itu, juga tidak mengabaikan pendapat dan pemahaman dari para ulama terdahulu terhadap suatu teks hadis. ${ }^{46}$

Dengan memperhatikan hal-hal di atas, maka diharapkan ada moderasi dalam penggalian tujuan Nabi (Maqasid profetik) dalam hadis beliau, dan tidak terjebak dalam salah satu pihak yang berlebihan dan liberal dalam menonjolkan Maqasid (Mufrith) sehingga mengeluarkan sunnah dari konteks asalnya, ataupun pihak tekstualis yang kaku berpegang pada zhahir lafalnya (Mufarrith).

\section{Maqasid Profetik dalam Hadis tentang Relasi Laki-laki dan Perempuan}

Laki-laki dan perempuan merupakan dua jenis makhluk yang tidak dapat hidup sendiri dan saling bergantung satu sama lain. Hadis yang berkaitan dengan kemitraan laki dan perempuan dapat dilihat dari riwayat Anas dan Aishah. Hadis dari jalur Anas sebagaimana diriwayatkan al-Darimi berbunyi:

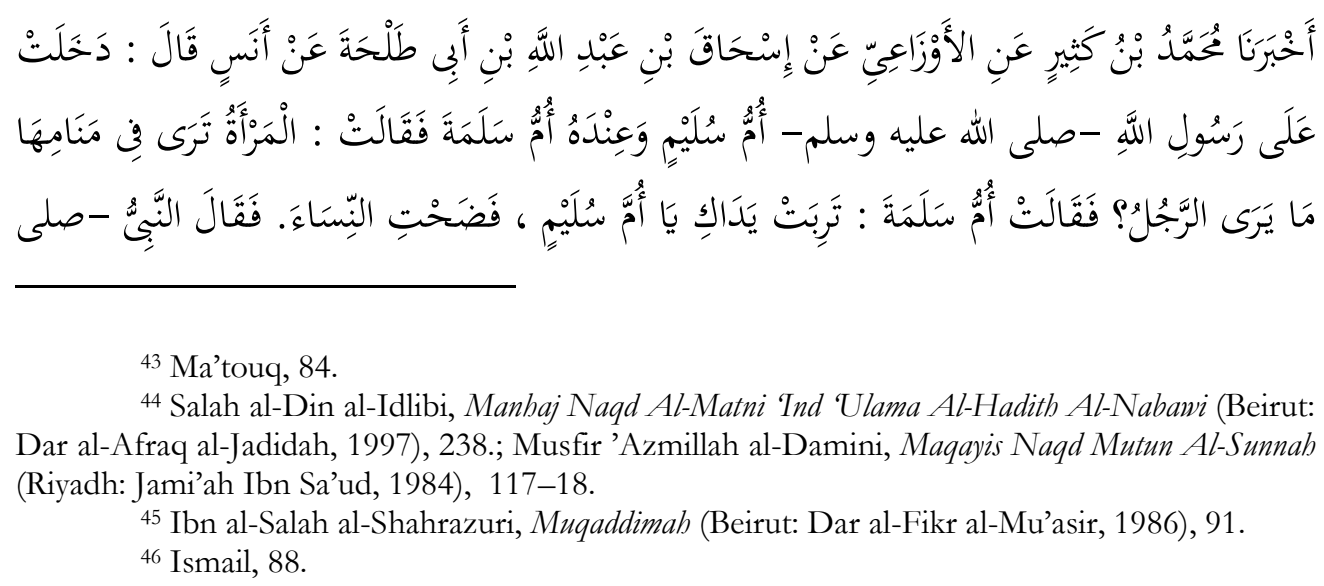

${ }^{44}$ Salah al-Din al-Idlibi, Manhaj Naqd Al-Matni Ind Ulama Al-Hadith Al-Nabawi (Beirut: Dar al-Afraq al-Jadidah, 1997), 238.; Musfir 'Azmillah al-Damini, Maqayis Naqd Mutun Al-Sunnab (Riyadh: Jami'ah Ibn Sa'ud, 1984), 117-18.

45 Ibn al-Salah al-Shahrazuri, Muqaddimah (Beirut: Dar al-Fikr al-Mu’asir, 1986), 91.

${ }^{46}$ Ismail, 88. 


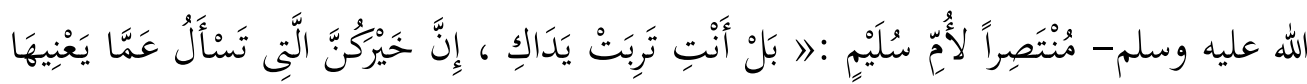

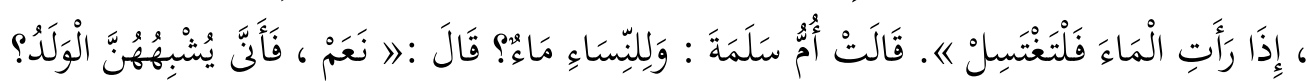

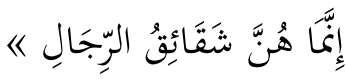

Mubammad ibn Kathir mengkabarkan kami, dari al-Awą'i, dari Ishaq ibn Abdillah ibn Abi Talhah, dari Anas berkata, Ummu Sulaym masuk menemui Nabi saw. yang pada saat itu ditemani oleh Ummu Salamah, istri beliau. Ummu Sulaym bertanya, "Perempuan yang bermimpi dalam tidurnya apakah sama dengan lelaki yang bermimpi dalam tidurnya?" Ummu Salamah berkata, "Wabai Ummu Sulaym, engkau telah membuka aib perempuan." Nabi saw. membela Ummu Sulaym dengan bersabda, "Sesunggubnya sebaik-baik dari kalian adalah yang menanyakan tentang hal-hal yang terkait dirinya, jikea perempuan melihat air (basah dalam pakaiannya) maka ia harus mandi." Ummu Salamah berkata, "Apakah perempuan juga memiliki air?", Nabi saw. menjawab, "Ya, sesunggubnya mereka adalab saudara kandung laki-laki. ',7

Adapun hadis dari jalur Aishah sebagaimana diriwayatkan Abu Dawud dan al-Tirmidzi berbunyi:

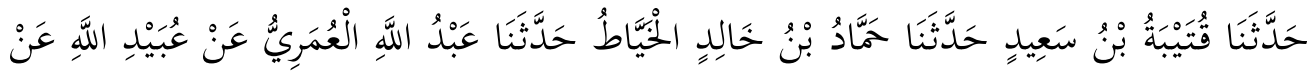

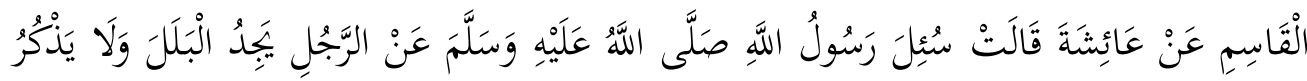

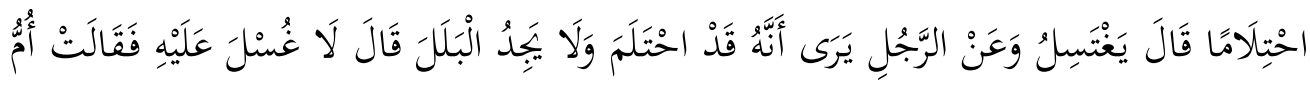

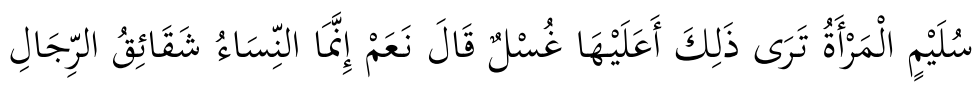
Qutaybah menyampaikan pada kami, Hammad ibn Khalid al-Khayyat menyampaikan pada kami, Abdullah al-Umary menyampaikan pada kami, dari Ubaydillah, dari al-Qasim, dari Aishah berkata, Nabi saw. ditanya tentang seorang laki-laki yang mendapati basah (usai tertidur) dan tidak bermimpi. Nabi saw. menjawab, "Ia harus mandi." (Beliau saw. ditanya kembali) tentang seorang laki-laki yang bermimpi dan tidak mendapati basah (dalam pakaiannya). Nabi saw. menjawab, "Ta tidak wajib mandi." Lalu, Ummu Sulaym bertanya, "Bagaimana dengan perempuan (yang mendapati basah dalam pakaiannya usai tertidur), apakah ia wajib mandi? Nabi saw. bersabda, "Ya, sesunggubnya perempuan itu adalah saudara kandung laki-laki»"s

47 Al-Darimi, Sunan, II (Beirut: Dar al-Fikr, 2003), 421.

${ }^{48}$ Sulayman ibn al-Asy'ats Abu Dawud, Sunan, I (Beirut: Dar al-Fikr, 1999), 299.; AlTirmidzi, 189. Perbedaan jalur sanad Abu Dawud dan al-Tirmidzi terletak pada murid Hammad ibn Khalid al-Khayyat dalam riwayat Abu Dawud dan Ahmad ibn Mani' dalam riwayat al-Tirmidzi. 
Hadis ini dari jalur Anas ibn Malik berkualitas sabib. ${ }^{49}$ Demikian pula dengan hadis dari jalur Aishah yang juga memiliki kualitas sabib. ${ }^{50}$ Pentingnya menguak Maqasid profetik dalam hadis-hadis tersebut bermaksud untuk mendorong kesetaraan dan keseimbangan relasi antara laki-laki dan perempuan. Hal ini juga berpijak dari tiga argumen: Pertama, Islam memberikan tempat yang terhormat kepada seluruh manusia, baik bagi laki-laki dan perempuan. Kedua, alQur'an sebagai sumber ajaran Islam yang utama secara norma-etis mendorong prinsip-prinsip kesetaraan perempuan dan laki-laki, yaitu: (1) Perempuan dan lakilaki merupakan representasi Tuhan di bumi dan memiliki tugas yang sama dalam memakmurkan bumi; (2) Perempuan dan laki-laki sama-sama mengemban amanah primordial; (3) Perempuan dan laki-laki sama-sama terlibat dalam drama kosmis; (4) Perempuan dan laki-laki memiliki kesempatan dan potensi yang sama untuk meraih prestasi. ${ }^{51}$ Ketiga, misi diutusnya Nabi saw. adalah mengajak manusia kepada Tauhid. Nabi saw. lahir dan diangkatsebagai utusan Tuhan, dalam kondisi-yang pada saat itu—diliputi dengan keyakinan dan ideologi politheistik yang mengabaikan arti kemanusiaan. ${ }^{52}$

Ajaran monotheistik yang diusung Nabi saw. merupakan statemen yang menegasikan segala bentuk politheisme, tidak hanya pada tataran ritualistik seperti penyembahan berhala, patung, dan sebagainya, namun juga pada segala bentuk kemusyrikan sosial dan politik seperti me-maha agung-kan dan memuja kepentingan-kepentingan pribadi, golongan, jenis kelamin tertentu, etnis dan sebagainya. Husein Muhammad menjelaskan pernyataan bahwa mengesakan Allah dalam konsep Taubid tidak sekadar sebuah pernyataan verbal saja, melainkan juga komitmen untuk menjadikan Taubid itu sebagai landasan utama dalam membangun tatanan sosial-politik-kebudayaan. Pada dimensi individual, Taubid berarti pembebasan manusia dari segala bentuk belenggu perbudakan dalam spektrum yang luas yaitu perbudakan manusia atas manusia, perbudakan diri terhadap benda, dan perbudakan diri terhadap segala bentuk kesenangan pribadi dan kebanggaan di hadapan orang lain serta hal-hal yang menjadi kecenderungan egoistik manusia. Pada dimensi sosial, tauhid mengandung makna pembebasan diri dari sikap tiran dan penolakan terhadap penindasan manusia lain atas nama apapun. Dengan demikian, afirmasi tauhid menunjukkan bahwa tidak ada

49 Muhammad Nasir al-Din al-Albani, Silsilah Al-Ahadis Al-Sabihab Wa Shai'un Min Fiqhiha Wa Fawaidiba, VI (Riyadh: Maktabah al-Ma'arif, 1995), 362.

50 al-Albani, Silsilab Al-Ahadis Al-Sabibah Wa Sbai'un Min Fiqbiba Wa Fawaidiba, 362.; Muhammad Nasir al-Din al-Albani, Sabib Wa Dha if Sunan Abi Dawud, I (Alexandria: Markaz Nour al-Islam), 314.; Muhammad Nasir al-Din al-Albani, Sabih Wa Dha'if Sunan Abi Al-Tirmidri, I (Alexandria: Markaz Nour al-Islam), 113.

51 Nurjannah Ismail, Perempuan Dalam Pasungan: Bias Laki-Laki Dalam Penafsiran (Yogyakarta: LKiS, 2003), 271-94.

52 Mulyadi, 57. 
kekuasaan dan kepemilikan mutlak manusia atas alam semesta. Seluruh kekuasaan dan kepemilikan atas segala sesuatu hanya ada pada Allah semata. ${ }^{53}$

Memahami hadis Innama al-Nisa Shaqa'iq al-Rijal dengan menggunakan pendekatan Maqasid profetik berarti menguak tujuan yang diperhatikan Nabi saw. saat menyabdakan hadis ini. Hadis ini berpotensi menjadi basis dalam membangun relasi yang seimbang antara laki-laki dan perempuan dalam berbagai aspek kehidupan, dan kedua jenis kelamin ini saling mendukung dalam memainkan perannya masing-masing. M. Quraish Shihab mengungkapkan bahwa shaqa'iq al-rijal berarti saudara kandung laki-laki. Ini mengindikasikan bahwa perempuan adalah mitra laki-laki. Oleh karena itu, keduanya memiliki kedudukan dan hak-hak yang sama. ${ }^{54}$

Kedudukan perempuan dan laki-laki dengan mengacu pada prinsip tauhid mengandung makna persamaan atau kesetaraan manusia secara universal. Keduanya sama-sama berpeluang menjadi hamba Allah yang ideal, dan mencapai derajat ketakwaan sebagai puncak spiritualitas yang paling tinggi (QS. al-Ma'idah: 8; al-Taubah: 71; al-Ahzab: 35). ${ }^{55}$ Ketakwaan sering didefinisikan sebagai takut kepada Tuhan dengan menjalankan perintah-perintah dan menjauhi laranganlarangan-Nya. Definisi ini sejatinya mengandung makna kesetaraan manusia di hadapan hukum-hukum Tuhan, sekaligus meniscayakan kesadaran manusia untuk selalu tunduk hanya kepada hukum-hukum universal. ${ }^{56}$

Sebagaimana dinyatakan sebelumnya, bahwa menguak Maqasid profetike memerlukan pengetahuan tentang situasi dikeluarkannya ujaran Nabi saw. dengan maksud untuk memperoleh pemahaman yang akurat atas suatu hadis. Secara konteks sosial empirik, hadis ini (baik dari jalur Anas ataupun Aishah) berkenaan dengan seseorang yang bertanya kepada Nabi saw. tentang laki-laki yang mendapati celananya basah saat bangun tidur, namun ia tidak ingat apakah ia mengalami mimpi basah berhubungan seksual ataukah tidak. Nabi saw. pun menetapkan bahwa orang tersebut harus mandi wajib. Orang tersebut bertanya kembali tentang seorang laki-laki yang bermimpi seks namun tidak mendapati celananya basah. Lalu Nabi saw. menjelaskan bahwa orang ini tidak harus mandi wajib. Ummu Sulaym juga bertanya tentang hal yang sama jika dialami seorang perempuan yang mimpi basah. Nabi saw. menjawab bahwa perempuan tersebut

\footnotetext{
${ }^{53}$ Husein Muhammad, Islam Agama Ramah Perempuan (Yogyakarta: LKiS, 2013), 5-8.

${ }^{54}$ M. Quraish Shihab, Membumikan Al-Qur'an; Tafsir Mawdhui atas Pelbagai Persoalan Umat..(Bandung: Mizan, 1992), 17.

${ }^{55}$ Nur Rofiah, Nalar Kritis Muslimah: Reflekssi Atas Keperempuanan, Kemanusiaan, dan Keislaman, (Bandung: Afkaruna, 2020), 36-40.

56 Muhammad, 9.
} 
juga harus mandi wajib, lalu Nabi saw. menegaskan bahwa perempuan itu adalah saudara kandung laki-laki. ${ }^{57}$

Pemahaman secara tekstual terhadap sebab disabdakannya hadis Innama al-Nisa Shaqäiq al-Rijal memang berkenaan dengan kewajiban bersuci bagi siapapun yang melihat pakaiannya basah setelah tertidur. Nabi saw. menetapkan bahwa hukum ini berlaku baik bagi laki-laki maupun bagi perempuan, karena bagaimanapun juga perempuan itu shaqa'iq laki-laki. Sedangkan pemahaman secara kontekstual terhadap hadis ini memberikan cakupan dan dampak yang lebih luas, tidak hanya terkait perihal bersuci saja, melainkan juga berkaitan dengan penetapan Nabi saw. bahwa antara keduanya itu adalah memiliki hubungan erat bagaikan saudara kandung. Pemaknaan demikian juga tidak lepas dari analisis linguistik dari shaqa'iq yang merupakan bentuk plural dari shaqiq. Kata shaqiq berarti saudara kandung, serupa, kembaran, dan identik. Kata ini sering dipadankan dengan kata ną̧hir dan matsil yang memiliki arti: sejawat, mitra, paralel, sederajat, analogi, duplikat, kembaran, dan ekuivalen. ${ }^{58}$ Oleh karenanya bisa dimengerti jika banyak ulama kontemporer yang memberikan pemaknaan terhadap hadis ini bahwa sejatinya perempuan adalah kembaran, identik, atau mitra laki-laki. Tidak jarang pula mereka menjadikan hadis ini sebagai dasar kesetaraan laki-laki dan perempuan. Salah satunya, Yusuf al-Qaradawi yang menjadikan hadis tersebut sebagai dasar umum bahwa perempuan memiliki hak dan kewajiban yang sama dengan laki-laki dalam beban, tugas, atau pekerjaan (takliff) mereka, kecuali jika ada dalil yang mengecualikannya. Ini artinya bahwa perempuan juga berpotensi untuk berbuat kebaikan dan meraih prestasi tidak hanya di ranah domestik saja, melainkan juga di ranah publik. ${ }^{59}$ Senada dengan alQaradawi, M. Quraish Shihab juga menyatakan bahwa hak antara laki-laki dan perempuan adalah sama. Seandainya pun ada yang berbeda, maka itu hanyalah akibat fungsi dan tugas-tugas utama yang dibebankan Tuhan kepada masingmasing jenis kelamin tersebut. Karenanya, hal ini tidak berkonsekwensi bahwa jenis kelamin tertentu merasa memiliki kelebihan atas yang lain. ${ }^{60}$

Penghormatan Nabi saw. terhadap perempuan telah terbukti sepanjang sejarah. Tidak hanya memberikan kedudukan yang mulia dan terhormat saja, melainkan juga menetapkan hak-hak mereka. ${ }^{61}$ Hak untuk hidup bermartabat, beragama, berkeluarga, berpolitik, beraktifitas dalam ruang lingkup sosial,

${ }^{57}$ Ibn Hamzah al-Husayni al-Dimasqy, Al-Bayan Wa Al-Ta'rif Fi Asbab Wurud Al-Hadith (Beirut: al-Maktabah al-Ilmiyah, 2007), 100.

${ }^{58}$ Ibn Mandzur al-Misri, X 182-83.

${ }^{59}$ Yusuf al-Qaradawi, Fatawa Mu'asirah (Kuwait: Dar al-Qalam, 2000), 479-90.

${ }^{60}$ Shihab, 435-36.

${ }^{61}$ Umma Farida, Abdurrohman Kasdi, 'The 2017 KUPI Congress and Indonesian

Female Ulama', Journal of Indonesian Islam, 12.2 (2018), 135-58. https://doi.org/10.15642/JIIS.2018.12.2.135-158. 
ekonomi, dan pendidikan. ${ }^{62}$ Secara lebih detil Haifaa A. Jawad mengelaborasi hakhak perempuan sebagai berikut: ${ }^{63}$

Pertama, hak untuk memiliki dan berpartisipasi dalam berbagai kegiatan ekonomi, seperti jual beli, pinjam meminjam, sewa menyewa, dan sebagainya didasarkan kepada prinsip-prinsip al-Qur'an dan hadis terutama prinsip yang menerangkan tentang mahar dan zakat yang mendukung perempuan untuk memiliki dan menabung, ataupun berinvestasi dan membelanjakan pendapatan mereka menurut kebijaksanaan mereka sendiri.

Kedua, hak untuk menikah dengan laki-laki pilihannya dan hak untuk mengakhiri perkawinan yang gagal. Nabi saw. menegaskan dalam sabdanya bahwa seorang janda tidak dapat dinikahkan sebelum diminta persetujuannya terlebih dahulu, demikian pula dengan gadis yang perlu ditanyai persetujuan nikahnya terlebih dahulu, dan tanda persetujuannya adalah sikap diamnya. Tidak hanya memiliki hak dalam menentukan pernikahannya saja, namun perempuan juga memiliki hak yang sama dengan laki-laki dalam mengajukan cerai apabila ternyata pernikahan yang dibinanya mengalami kegagalan dengan mengajukan kbulu', yaitu pengajuan cerai dari istri dengan memberikan tebusan berupa sejumlah harta yang ia miliki. ${ }^{64}$

Ketiga, hak untuk memperoleh pendidikan, bahkan Nabi saw. telah memberikan waktu khusus bagi perempuan untuk memperdalam pengetahuan agamanya. Kempat, hak untuk menggunakan identitasnya sendiri, bukan nama suaminya. ${ }^{65}$ Kelima, hak untuk memperoleh kenikmatan seksual, bahkan Nabi saw. mengkategorikan seks dalam hubungan pernikahan yang sah sebagai perbuatan yang menunjukkan ketaatan kepada Tuhan dan kelak akan dijanjikan pahala di akhirat ${ }^{66}$ Keenam, hak untuk ikut mewarisi, baik dari orang tuanya, suami, maupun dari kerabat laki-lakinya (QS. al-Nisa : 7). Ketujuh, hak untuk berpartisipasi dalam persoalan-persoalan politik. Nabi saw. mendorong perempuan untuk aktif dalam bidang politik dan berkontribusi dalam pengambilan keputusan. Perempuan diberi kesempatan untuk mengekspresikan diri mereka (QS. al-Mumtahanah : 12), untuk berdebat (QS. al-Mujadalah : 1), untuk mengemukakan pemikiran mereka di depan publik, menjadi delegasi Qalam, 2002).

${ }^{62}$ Abd al-Halim Abu Shuqqah, Tahrir Al-Mar'ah Fi Asr Al-Risalah (Kuwait: Dar al-

${ }^{63}$ Haifaa A. Jawad, Otentisitas Hak-Hak Perempuan: Perspektif Islam Atas Kesejabteraan Jender (Yogyakarta: Fajar Pustaka Baru, 2002), 16-25.

${ }^{64}$ Ibn Hajar al-Asqalani, Fath Al-Bari, IX, (Beirut: Dar al-Kutub al-Ilmiyah, 2000), 239494; Hamim Ilyas, Perempuan Tertindas? Kajian Hadis-hadis Misoginis, (Yogyakarta: Elsaq Press, 2005), 121-190.

65 A.Jawad, 21.

${ }^{66}$ Ibn Hibban al-Tamimi, Sunan, IX (Beirut: Muassasah al-Risalah, 1993), 503. 
sebagaimana yang pernah dilakukan oleh Nusaybah dan Asma. Keduanya adalah dua orang perempuan yang termasuk anggota delegasi yang berjumlah 75 orang, datang untuk meminta izin kepada Nabi saw. agar diperkenankan hijrah dari Makkah ke Madinah. ${ }^{67}$ Pertimbangan atau pendapat mereka dalam persoalanpersoalan politik mempunyai nilai yang tinggi dan dihormati, serta mempunya pengaruh yang besar dalam membentuk masyarakat di mana mereka berada. Aishah dan Ummu Salamah (keduanya istri Nabi saw.) adalah contoh yang paling jelas dalam hal ini. Ummu Salamah adalah penasehat Nabi saw. dalam bidang politik yang cerdas dan sering bertindak sebagai pemimpin bagi kaum perempuan. Aishah juga telah memainkan peran penting dalam area politik dan melibatkan diri dalam perang Jamal, serta tidak segan mengkritisi kebijakan dari pemerintah. ${ }^{68}$

Kemitra-sejajaran laki-laki dan perempuan sebagaimana tampak dalam ujaran dan sikap Nabi saw. di atas tidak jarang pula dihadapkan pada hadis-hadis lain yang menunjukkan superioritas laki-laki atas perempuan. Salah satunya ditemukan dalam hadis tentang larangan istri meminta cerai kepada suami. Dalam hadis tersebut dinyatakan bahwa siapapun perempuan (istri) yang meminta cerai dari suaminya tanpa alasan yang dibenarkan, maka ia tidak akan mencium aroma surga: ${ }^{69}$

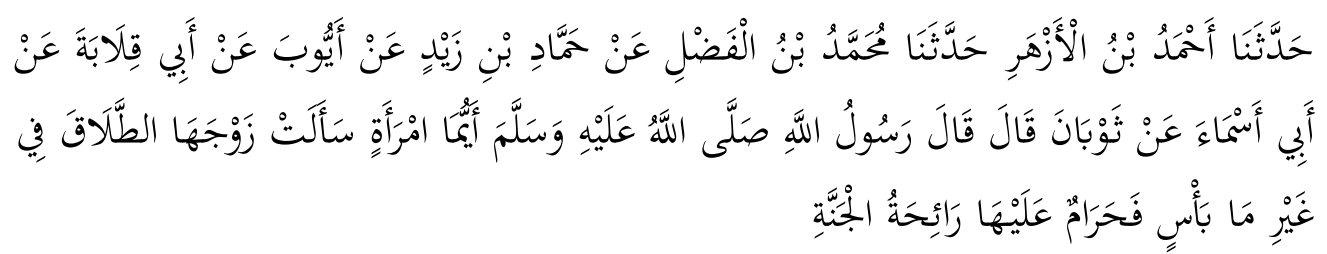

Ahmad ibn al-Azhar menyampaikan kepada kami, Mubammd ibn al-Fadl menyampaikan kepada kami, Hammad ibn Zayd menyampaikan kepada kami, dari Ayyub, dari Abu Qilabah dari Abu Asma" dari Sauban berkata, Nabi saw. bersabda, "Siapapun perempuan yang meminta cerai pada suaminya tanpa alasan yang dibenarkan, maka ia tidak akan mencium aroma surga."

Secara tekstual, hadis di atas menunjukkan bahwa hak mengajukan gugatan cerai hanya berlaku bagi laki-laki (suami) dan tidak berlaku bagi perempuan (istri). Kesan diskriminatif semakin diperkuat dengan ketetapan hukum Islam (fiqh) yang cenderung mempermudah proses perceraian bagi suami, misalnya dengan cukup mengatakan 'saya menceraikan kamu' (anti thaliqab 'alayya) maka telah jatuh talaknya karena termasuk dalam kategori redaksi talak yang tegas (sharib). Bahkan, hal ini juga didukung oleh hadis yang menyatakan bahwa cerai atau talak yang dilakukan dengan kesungguhan hati ataupun hanya main-main,

${ }^{67}$ Said Abdullah al-Hatimi, Women in Islam: A Comparative Study (Lahore: Islamic Publication, 1993), 51.

68 A.Jawad, 55-56.

${ }^{69}$ Abu Dawud, VI 142.; Al-Tirmidzi, IV 432-33.; Al-Darimi, VII 73. 
maka tetap jatuh talaknya. ${ }^{70}$ Dengan demikian, teks-teks hadis yang ada seakan saling berhadapan dan kontradiktif, padahal kebohongan dan inkonsistensi tidak dibenarkan ada dalam diri Nabi saw., karena beliau adalah pribadi yang terjaga (ma'sum). Oleh karena itu, perlu pemahaman yang tepat sehingga kontradiksi atas ujaran Nabi saw. yang terangkum dalam hadis-hadis beliau yang akurat tidak terjadi.

Hadis-hadis Nabi saw. yang hadir dalam sebuah kebudayaan yang sangat diskriminatif terhadap perempuan, bahkan membenci mereka (misogynis) memerlukan pemahaman yang komprehensif terhadapnya. Sebab dalam komunitas seperti ini, kebiasaan dan tata cara hidup mereka yang tidak menghargai perempuan perlu didekontruksi melalui perubahan-perubahan transisional secara gradual dan evolutif. Melalui teks-teks hadis yang disabdakan, sejatinya Nabi saw. berusaha melakukan transformasi kultural secara arif dan realistik. Upaya ini tidak hanya berkaitan dengan relaki laki-laki dan perempuan saja, atau bahkan hak gugat cerai secara spesifik, namun merupakan pola umum kebijakan Nabi saw. Oleh karena itu, hadis Nabi saw. yang mengafirmasi norma-norma hukum mengandung aspek-aspek logika rasional (ma'qul al-ma'na). Ini dimaksudkan untuk memberi peluang yang luas bagi upaya-upaya perluasan makna dan transfornasu lebih lanjut, sejalan dengan berubahan-perubahan sosial dan kultural yang menyertainya. $^{71}$

Para muhaddisin telah menetapkan beberapa kaidah dalam menyikapi adanya kontradiksi dalam hadis, yakni menggabungkan dua makna atau maksud yang terkandung dalam matan hadis yang bertentangan (jam'u). Jika langkah pertama ini tidak memungkinkan untuk ditempuh maka diambil langkah kedua yaitu melacak waktu penyabdaan dua hadis kontradiktif tersebut mana yang lebih dahulu disabdakan Nabi saw. dan mana hadis yang lebih belakangan disabdakan beliau, atau yang dikenal dengan naskh. Dengan mengaplikasikan naskh ini maka hadis yang belakangan disabdakan Nabi saw. merupakan hadis yang menghapus hadis yang disabdakan oleh Nabi saw. yang terdahulu. Adapun jika langkah kedua tidak dapat ditempuh maka perlu diterapkan metode tarjih dengan cara mengunggulkan salah satu hadis di antara hadis-hadis yang kontradiktif tersebut dengan melihat pada ciri dan kualitas masing-masing hadis. ${ }^{72}$

70 Abu Dawud, V 109; Al-Tirmidzi, IV 427; Ibn Majah, VI 2018.. Hadis ini berbunyi:

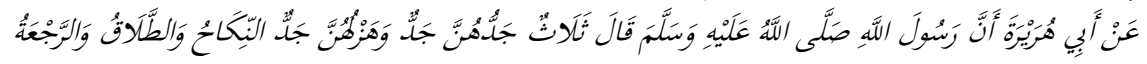

${ }^{71}$ Muhammad, 16-18.

${ }^{72}$ Zuhad, Metode Pemahaman Hadis Mukbtalif dan Asbab al-Wurud, (Semarang: Rasail, 2011), 5 . 
Hadis larangan perempuan menggugat cerai jika dilihat dari aspek sanadnya menunjukkan adanya ketersambungan sanad (ittishal) dan diriwayatkan oleh para periwayat yang mayoritas terpercaya kecuali Muhammad ibn al-Fadl yang memiliki kelemahan dari aspek kualitas hafalnnya. Para kritikus hadis menilainya sebagai seorang mukhtalith (rancu hafalannya). Sehingga hadis ini hanya bisa dikategorikan sebagai hadis hasan. ${ }^{73}$ Sedangkan dari aspek matannya, hadis ini juga tidak ada kerancuan redaksi dari aspek struktur bahasa maupun logika. Namun kesan kontradiktif ditemukan karena hadis ini bertentangan dengan hadis yang membolehkan perempuan menggugat cerai dengan memberikan tebusan (kbulu') sebagaimana yang dijelaskan dalam hadis sabih berkenaan dengan seorang sahabat perempuan yang bernama Habibah yang menuntut cerai dari suaminya, Thabit ibn Qays. Habibah meminta cerai karena tidak mencintai dan tidak suka dengan kondisi fisik suaminya, serta mengkhawatirkan tidak sanggup berbuat baik terhadap suaminya. ${ }^{74}$

Dalam Islam, pernikahan merupakan penyatuan dua orang dewasa yang didasari oleh kemauan bersama dengan tujuan untuk melanggengkan kehidupan manusia dan mencapai keharmonisan spiritual serta emosional (QS. al-Rum : 2021). Persetujuan dan kerelaan dari kedua belah pihak merupakan sebuah esensi untuk memulai sebuah relasi pernikahan, ataupun mengakhirinya. Dengan merujuk dari pendapat para muhaddisin di atas dalam menyelesaikan kontradiksi maka pertentangan antar hadis dapat dihilangkan dengan cara kompromi (aljam' $u$ ). Bentuk komprominya adalah bahwa kedua hadis tersebut (yakni hadis yang melarang dan membolehkan menuntut cerai) keduanya dapat diamalkan, namun dalam konteks yang berbeda. Maksudnya, larangan perempuan meminta cerai itu hanya berlaku jika permintaan cerai itu dilakukan tanpa alasan yang dibenarkan secara Syariat, sebagaimana penegasan Nabi saw. dalam hadis tersebut, yaitu min ghayri ma ba's (permohonan cerai tanpa alasan). Adapun jika ada alasan-alasan yang dapat dibenarkan dalam gugatan cerai seperti suami tidak memberi nafkah lahir maupun batin, suami pemabuk, penjudi, dan lainnya, maka istri berhak untuk menggugat cerai suaminya. ${ }^{75}$

Ditinjau dari perspektif Maqasid, larangan Nabi saw. di atas merupakan upaya preventif beliau (sadd al-drari'ah) supaya siapapun baik laki-laki ataupun perempuan secara serampangan menggugat cerai. Sebaliknya, jika perceraian itu

73 Abdul Mustaqim, Ilmu Ma'anil Hadits: Paradigma Interkoneksi (Yogyakarta: Idea Press, 2008), 140-41.

${ }^{74}$ Al-Bukhari, VI, 320. Teks hadis selengkapnya berbunyi:

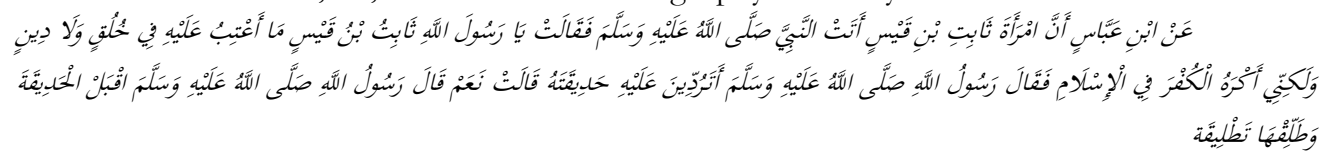


dipandang lebih dapat membawa kebaikan atau maslahat, maka tentu itu lebih baik daripada tidak bercerai, karena mewujudkan kemaslahatan itu tujuan dari penetapan hukum Islam.

Dengan demikian, relasi yang berimbang dan harmonis antara laki-laki dan perempuan menjadi Maqasid Nabi saw. dalam setiap ujaran dan kebijakan yang ditetapkannya. Keseimbangan relasi dengan bersandar pada pemahaman yang tepat dan komprehensif terhadap ujaran dan ajaran Nabi saw. membuka kesempatan dan peluang bagi kaum perempuan untuk memainkan peran-peran dalam berbagai ruang sejarah, ruang privat, dan publik.

Berkaca pada sejarah kehidupan Nabi saw. bahwa para perempuan zaman Nabi saw. pun telah banyak yang menekuni profesi tertentu dan beraktifitas di ruang publik. Istri beliau, Khadijah binti Khuwailid adalah pedagang yang sangat ulung dan berhasil. Zaynab binti Jahsy sebagai penyamak kulit, dan Ummu Sulaym binti Milhan dikenal sebagai perias pengantin yang handal. Mereka semua menjalankan profesinya dan Nabi saw. tidak pernah melarang mereka untuk menghentikan profesi yang mereka tekuni. Bahkan, kaum perempuan bahumembahu bersama kaum lelaki dalam berperang menegakkan Islam. Rufaydah alAslamiyah menjadi pelopor untuk memberi air dan mengobati para jihadis yang terluka dalam peperangan. Bahkan Nusaybah pernah terlibat langsung peperangan bersama Nabi saw. dalam perang Uhud. ${ }^{76}$ Nabi saw. sebagai pembawa risalah secara revolusioner telah memposisikan perempuan secara terhormat sebagai mitra-sejajar laki-laki. ${ }^{77}$ Fakta historis ini seharusnya dapat membuka mata kita untuk melakukan reinterpretasi dengan menggunakan pendekatan Maqasid profetik terhadap teks-teks hadis, terutama hadis-hadis yang terkesan misogynis.

\section{Kesimpulan}

Sabda, ujaran, dan perbuatan Nabi saw. yang terangkum dalam hadis senantiasa menginspirasi dan mempengaruhi tradisi kehidupan umat Islam seharihari, termasuk hadis tentang relasi laki-laki dan perempuan. Pemahaman terhadap hadis dapat dikontekstualisasikan dengan menggali tujuan-tujuan dan orientasi Nabi saw. (Maqasid profetik) selaku sumber hadis dalam menyabdakan hadis tersebut, sehingga dapat meminimalisir bahkan menghindarkan kesan misogynisdiskriminatif dalam memahami hadis. Menguak Maqasid profetik dari hadis-hadis Nabi saw. meniscayakan untuk memperhatikan beberapa kaidah yaitu: Pertama, kontekstualisasi makna hadis tidak boleh mereduksi makna tekstual teks. Kedua,

${ }^{76}$ Umma Farida, 25 Perempuan Teladan: Para Istri, Putri Dan Sababat Perempuan Nabi (Yogyakarta: Idea Press), 2-134.

${ }^{77}$ Nur Rofiah, 40. 
Penerapan pemahaman Maqasidi tidak berlaku pada hadis-hadis yang berkaitan dengan hal-hal yang sifatnya Tauqifi. Ketiga, mengutamakan pada tujuan (Maqasid) yang menjadi prioritas dan paling penting, serta mengedepankan kemaslahatan universal yang berpijak pada prinsip-prinsip umum dalam Islam, seperti prinsip keadilan, kesetaraan, kesamaan dalam hukum, kasih sayang, menghindarkan kesulitan dan bahaya.. Keempat, penggunaan Maqasid untuk memahami hadis tidak mengakibatkan pertentangan dengan teks-teks Islam yang mengandung petunjuk pasti, atau menyelisihi tujuan umum yang telah disepakati para ulama.

Hadis tentang relasi laki-laki dan perempuan yang diriwayatkan al-Darimi dari jalur Anas ibn Malik berkualitas sabih. Demikian pula dengan hadis yang diriwayatkan Abu Dawud dan al-Tirmidzi dari jalur Aishah juga memiliki kualitas sabih. Memahami hadis-hadis tersebut dengan menggunakan pendekatan Maqasid profetik berarti menguak tujuan yang diperhatikan Nabi saw. saat menyabdakan hadis ini. Hadis ini berpotensi menjadi basis dalam membangun relasi yang seimbang antara laki-laki dan perempuan dalam berbagai aspek kehidupan. Melalui hadis ini, maka dapat dipahami bahwa secara fakta historis-empirik, Nabi saw. telah memberikan kedudukan, hak, dan kesempatan yang sama bagi laki-laki dan perempuan untuk berprestasi. Seandainya pun ada yang berbeda, maka itu hanyalah akibat fungsi dan tugas-tugas utama yang dibebankan Tuhan kepada masing-masing jenis kelamin tersebut. Karenanya, hal ini tidak berkonsekwensi bahwa jenis kelamin tertentu merasa memiliki keunggulan atas yang lain.

\section{Bibliografi}

A.Jawad, Haifaa. Otentisitas Hak-Hak Perempuan: Perspektif Islam Atas Kesejabteraan Jender. Yogyakarta: Fajar Pustaka Baru, 2002.

Abd al-Karim, Khalil. Mujtama Yatsrib Alaqah Al-Rajul Wa Al-Mar'ah Fi Abd AlNabiy Wa Al-Kbulafa Al-Rasyidin. Cairo: Sina li al-Nasyr, 1997.

Abu Dawud, Sulayman ibn al-Asy'ats. Sunan. Beirut: Dar al-Fikr, 1999.

Abu Shuqqah, Abd al-Halim. Tahrir Al-Mar'ah Fi Asr Al-Risalah. Kuwait: Dar alQalam, 2002.

Al-Albani, Muhammad Nasir al-Din. Sabih Wa Dha'if Sunan Abi Al-Tirmidzi. Alexandria: Markaz Nour al-Islam.

—. Sabih Wa Dha'if Sunan Abi Dawud. Alexandria: Markaz Nour al-Islam.

Silsilah Al-Abadis Al-Sabihah Wa Shai'un Min Fiqbiba Wa Fawaidiba. Riyadh: Maktabah al-Ma’arif, 1995.

Al-Asqalani, Ibn Hajar. Fath Al-Bari. Beirut: Dar al-Kutub al-Ilmiyah, 2000.

Al-Azami, Muhammad Mustafa. Studies in Hadith Methodology and Literature. Indianapolis: American Trust Publications, 1977. 
- Dirasat Fi Al-Hadis an-Nabawi Wa Tarikh Tadwinih. Beirut: Al-Maktab alIslami, 1992.

Al-Bukhari, Muhammad ibn Ismail ibn Ibrahim ibn al-Mughirah ibn Bardizbah. Al-Jami' Al-Sabih. Cairo: Dar al-Rayyan, 1997.

Al-Damini, Musfir'Azmillah. Maqayis Naqd Mutun Al-Sunnah. Riyadh: Jami'ah Ibn Sa'ud, 1984.

Al-Darimi, Abd al-Rahman al-Fadl ibn Bahram. Sunan, II, Beirut: Dar al-Fikr, 2003.

Al-Dimasqy, Ibn Hamzah al-Husayni. Al-Bayan Wa Al-Ta'rif Fi Asbab Wurud AlHadith. Beirut: al-Maktabah al-Ilmiyah, 2007.

Al-Hatimi, Said Abdullah. Women in Islam: A Comparative Study. Lahore: Islamic Publication, 1993.

Al-Idlibi, Salah al-Din. Manhaj Naqd Al-Matni Ind Ulama Al-Hadith Al-Nabawi. Beirut: Dar al-Afraq al-Jadidah, 1997.

Al-Ied, Ibn Daqiq. Ibkam Al-Abkam Syarh Umdat Al-Abkam. Matba'ah al-Sunnah al-Muhammadiyah, 1982.

Al-Kaylani, Abdullah Ibrahim Zayd. Atsar Al-Maqasid Al-Jur'iyyah Wa Al-Kulliyyah Fi Fabm Al-Nushush Al-Shar'iyyah: Dirasab Tathbiqiyyah Min Al-Sunnah AlNabawiyyah. Yordania: University of Jordan, 2006.

Al-Khadimi, Nur al-Din. Al-Ijtihad Al-Maqasidi Huijiyyatubu, Dhawabithubu, Majalatubu Qatar: Wizarah al-Awqaf wa al-Syu'un al-Islamiyyah, 1998.

Al-Naisaburi, Muslim bi al-Hajjaj Abu al-Hasan al-Qusyairi. Al-Jami’ Al-Sabih. Beirut: Dar al-Fikr, 2001.

Al-Qaradawi, Yusuf. Al-Sunnah Mashdaran Li Al-Ma'rifah Wa Al-Hadharah. Cairo: Dar al-Shorouk, 1998.

- Kayfa Nata'amal Ma'a Al-Sunnah Al-Nabawiyah. Cairo: Dar al-Shorouk, 2000.

—. Fatawa Mu'asirah. Kuwait: Dar al-Qalam, 2000.

—. Fi Fiqh Al-Awlawiyyat. Cairo: Maktabah Wahbah, 1999.

Al-Qarafi, Syihab al-Din. Al-Furuq. Beirut: Dar al-Kutub al-Ilmiyah, 2009.

Al-Qurtubi, Abu al-Abbas Ahmad ibn Umar. Al-Mufbim Lima Asykala Min Talkhish Kitab Muslim. Damaskus: Dar Ibn Katsir, 1996.

Al-Raisuni, Ahmad. Nąhariyyah Al-Maqasid 'Ind Al-Imam Al-Shatibi. Rabat: Dar al-Aman, 1991. 
840 | AL QUDS : Jurnal Studi Alquran dan Hadis vol. 5, no 2, 2021

Al-Salam, Izzuddin Ibn Abd. Al-Qawa'id Al-Sughra. Beirut: Dar al-Fikr al-Mu'asir, 1996.

Al-Shahrazuri, Ibn al-Salah Muqaddimah. Beirut: Dar al-Fikr al-Mu'asir, 1986.

Al-Shatibi, Ibrahim ibn Musa. Al-Muwafaqat Fi Usul Al-Sbari'ah. Qatar: Qatar Foundation, 2012.

Al-Siba'i, Mustafa. Al-Sunnah Wa Makanatuha Fi Al-Tashri' Al-Islami. Beirut: Dar al-Fikr, 2001.

Al-Suyuti, Jalal al-Din. Al-Ashbah Wa Al-Nazhair. Aleppo: Maktabah al-Bab alHalabi, 2000.

Al-Tamimi, Ibn Hibban. Sunan. Beirut: Muassasah al-Risalah, 1993.

Al-Tirmidzi, Abu Isa Muhammad ibn Isa. Sunan. Beirut: Dar al-Fikr, 2000.

Ashour, M. al-Tahir Ibn. Maqasid Al-Shari'ah Al-Islamiyyah. Amman: Dar al-Nafais, 2004.

Charbgoo, Abdullah Mohammad, Fatima Hafiz Irshudul Haq, Kassem Ali Saad, 'The Effect of the Purposes of Shari'a on the Understanding of Hadiths', Majallah Al-Shariqah Li Al-Ulum Al-Shar'iyyah Wa Al-Dirasat Al-Islamiyyah, 16.1 (2019), 27-61

Farida, Umma. 25 Perempuan Teladan: Para Istri, Putri Dan Sababat Perempuan Nabi. Yogyakarta: Idea Press.

Farida, Umma, Abdurrohman Kasdi. 'The 2017 KUPI Congress and Indonesian Female Ulama', Journal of Indonesian Islam, 12.2 (2018), 135-58. https://doi.org/10.15642/JIIS.2018.12.2.135-158

Farida, Umma, Abdurrohman Kasdi. 'Women's Roles in Ihya 'Ulum Al-Din and Method of Teaching It at Pesantrens in Indonesia', Al-Jami'ah Journal of Islamic $\quad$ Studies, $59.1 \quad$ (2021), https://doi.org/10.14421/ajis.2021.591.

Ibn Mandzur al-Misri, Muhamad bin Mukrim. Lisan Al-Arab. Beirut: Dar Shadir, 1990.

Ibrahim, Abdul Syukur. Metode Analisis Teks Dan Wacana. Yogyakarta: Pustaka Pelajar, 2009.

Ilyas, Hamim. Perempuan Tertindas? Kajian Hadis-hadis Misoginis. Yogyakarta: Elsaq Press, 2005.

Ismail, Abdelhamid Majid. 'The Relationship of the Science of the Makassed of Sharia to Hadeeth Science', Majallah Al-Ijtihad Li Al-Dirasat Al-Qanuniyah Wa Al-Iqtisadiyah, 8.2 (2019), 69-89 
Ismail, Nurjannah. Perempuan Dalam Pasungan: Bias Laki-Laki Dalam Penafsiran. Yogyakarta: LKiS, 2003.

Jakfar, Tarmizi M. Otoritas Sunnah Non-Tasyri'zyyah Menurut Yusuf Al-Qaradhawi. Yogyakarta: Arruzz Media, 2011.

Kadarusman. Agama, Relasi Gender \& Feminisme. Yogyakarta: Kreasi Wacana, 2005.

Ma'touq, Hasan Abdullah Hasan. Al-Bu'd Al-Maqasidi Li Al-Hadis Al-Sharif Wa Tathbiqatibi ind Al-Fuqaha. Palestina: al-Najah al-Wataniyyah University, 2018.

Majah, Muhammad Ibn. Sunan. Beirut: Dar al-Fikr, 1998.

Muhammad, Husein. Islam Agama Ramah Perempuan. Yogyakarta: LKiS, 2013.

Mulyadi. 'Relasi Laki-Laki Dan Perempuan: Menabrak Tafsir Teks, Menakar Realitas', Al-Ihkam, IV.1 (2009).

Mustaqim, Abdul. Ilmu Ma'anil Hadits: Paradigma Interkoneksi. Yogyakarta: Idea Press, 2008.

Ramle, Muhammad Rozaimi. 'Fahm Al-Hadits Fi Dhau'i Al-Maqasid AlShar'iyyah: Ta'shil Wa Fawa'id Wa Dhawabith', Journal of Hadith Studies, 2015, 7-28

Rofiah, Nur. Nalar Kritis Muslimab: Reflekssi Atas Keperempuanan, Kemanusiaan, dan Keislaman. Bandung: Afkaruna, 2020.

Shihab, M. Quraish. Membumikan Al-Qur'an; Tafsir Mawdhui atas Pelbagai Persoalan Umat. Bandung: Mizan, 1992.

Ya'qub, Ali Mustafa. Haji Pengabdi Setan. Jakarta: Pustaka Firdaus, 2006.

Zuhad. Metode Pemahaman Hadis Mukbtalif dan Asbab al-Wurud. Semarang: Rasail, 2011. 
842 | AL QUDS : Jurnal Studi Alquran dan Hadis vol. 5, no 2, 2021

Halaman kosong 